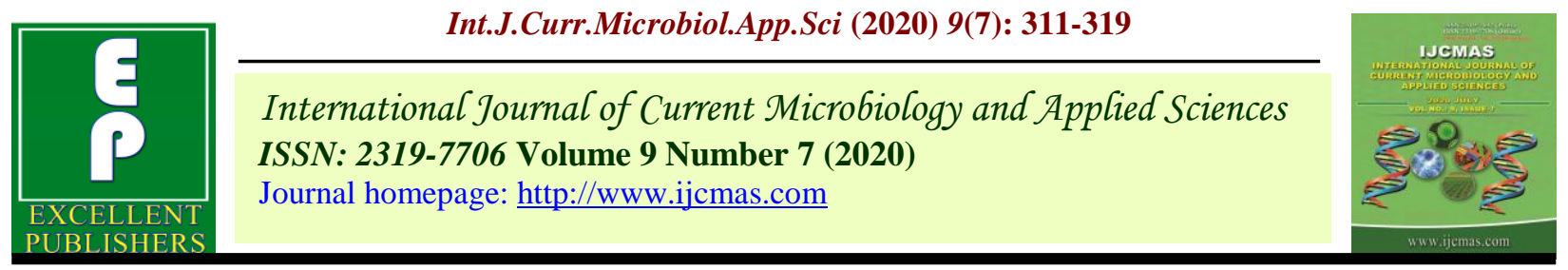

Original Research Article

https://doi.org/10.20546/ijcmas.2020.907.033

\title{
Evaluation of Sensory Characteristics and Storage Stability of Formulated Product from Persimmon (Diospyros kaki) Fruit
}

\author{
Medha Pandey, Kanchan Goswami*, Himani Joshi and Pratima Awasthi \\ Department of Foods and Nutrition, College of Home Science, \\ G.B.P.U.A\&T, Pantnagar, Uttarakhand, India \\ *Corresponding author
}

\begin{tabular}{l} 
Ke y w o r d s \\
Aonla, Hachiya, \\
Persimmon fruit, \\
Sensory \\
characteristics, \\
Storage stability \\
\hline Article Info \\
\hline $\begin{array}{l}\text { Accepted: } \\
\text { 05 June } 2020 \\
\text { Available Online: } \\
\text { 10 July } 2020\end{array}$ \\
\hline
\end{tabular}

Keywords

Aonla, Hachiya,

characteristics,

Storage stability

Available Online.

\section{A B S T R A C T}

\section{Introduction}

The persimmon fruit is of Japanese origin and is commonly grown in warm regions of the world. There are four species of Diospyros, namely, Diospyros kaki, Diospyros virginiana, Diospyros oleifera and Diospyros lotus out of which D. kaki (Japanese persimmon) is the most important species from nutritional point of view (Rahman et al., 2002). Persimmons are abundant in some nutrients, such as vitamin C $(70 \mathrm{mg} / 100 \mathrm{~g}$ pulp), vitamin A (65 mg/100 g pulp), calcium
(9 mg/100 g pulp), and iron $(0.2 \mathrm{mg} / 100 \mathrm{~g}$ pulp) (Tous et al., 1996). They contain bioactive compounds such as ascorbic acid, condensed tannins and carotenoids, which have many beneficial effects due to their antioxidant properties (Plaza et al., 2011).

An important feature of the some persimmon cultivars is the high soluble tannin content responsible for astringency. Astringency is the sensation that results when tannins bind salivary proteins and cause them to precipitate or aggregate, which leaves a rough 
"sandpapery" or dry sensation in the mouth. According to the level of astringency upon harvest, persimmon cultivars can be classified into two general categories: astringent and non-astringent persimmons (also called 'sweet' persimmons) (Yonemori et al., 2003).

In 2011, persimmon production has been reported over than 4.3 million ton throughout the world. China with production share of $74 \%$ (3.2 million ton) is the number one producer and Korea and Japan came second and third with $9 \%$ and $4.8 \%$, respectively (FAOSTAT, 2012). In India, persimmon is grown in the states like Himachal Pradesh, Jammu and Kashmir, Uttarakhand and Tamil Nadu.

Persimmon was traditionally used for medicinal purposes, e.g. treating coughs, hypertension, paralysis, frostbite, burns and bleeding; its fruit was consumed fresh or dried and trees were planted for ornamental purposes and wood (Ferrini and Pennati, 2008, Luo and Wang, 2008). As a good source of primary metabolites (particularly rich in sugars) and many nutritional antioxidants, carotenoids and polyphenols, it is now a popular and widespread fruit species in temperate to tropical regions (George and Redpath, 2008).

Persimmon resembles ripened tomatoes and thus attracts fruit lovers. The fruit is very sweet with an admirable flavor. The fruit must be fully ripe before being consumed or else it leads to puckering of mouth due to its astringent taste of tannic acid, yet the ripe fruit is a real treat. Persimmon fruits are delicious when still fresh, or they can be used in a variety of baked goods such as puddings, bread and cookies. The non-astringent varieties, such as Fuyu and Jirg, may be consumed when the fruits have developed full colour. The non-astringent fruit can be eaten while still firm. The flavor and texture of the fruit are quite pleasant. However, the astringent varieties such as Hachiya must be softened completely before use and are preferable for use in baked goods (Singh et al., 2011).

Among the fruits, persimmon (Diospyros $k a k i)$ is a popular and widespread fruit that is enriched with many bioactive compounds, including polyphenols, terpenoids, steroids, flavonoids, carotenoids, minerals, and dietary fiber (Karaman et al., 2014 and Zhao et al., 2011). Some components like phenolics, antioxidants, sterols, and flavonoids have a beneficial effect on human health owing to their ability to prevent or control various ailments (Karaman et al., 2014 and Dauchet et al., 2006).

These bioactive components play an important role in reducing arterial stiffness and prevent oxidation of low-density lipoproteins (LDL) thus resulting in the prevention of atherosclerotic plaque formation (Suzuki et al., 2010). Many phytochemicals also possess antimutagenic effects and regulate and trigger the immune system, thus resulting in the normal functioning of metabolism (Butt and sultan, 2009).

A number of them also serve as chemopreventive(Ruskin et al., 2002), anticancer, anti-inflammatory, and immunomodulatory agents (Parab et al., 2003 and Miller et al., 2004). Hence, persimmon, like other fruits, contains a number of functional compounds which are useful in promoting human health.

Nowadays, consumers demand high quality products with acceptable appearance, flavour, taste, and texture, as well as good nutritional value after processing. Therefore, determining the properties of food products during their shelf life is critical for research and development centres in the food industry. 
Hence keeping in view aforesaid points present study was planned to develop product using persimmon fruit and evaluate its sensory qualities and storage stability.

\section{Materials and Methods}

Hachiya variety (seedless) of Persimmon fruits were obtained from the local market of Bhowali; Distt. Nainital (Uttarankhand) and information regarding the variety was obtained from National Bureau of Plant Genetics Research Center (NBPGR), Bhowali.

\section{Physical characteristics of fresh persimmon fruit}

Weight, length and diameter of fruits: The fruits were weighed on an electrical balance in gram. Length and diameter of fruits were measured with the help of Vernier caliper in $\mathrm{mm}$. Fruit pulp and peel percentage: Previously weighed fruit samples were used for determining fruit pulp and peel percentage. The fruit pulp and peel percentage were calculated using following formulae:

Pulp $(\%)=\frac{\text { Weight of fruit pulp }}{\text { Weight of fruit }} \times 100$

Peel $(\%)=\frac{\text { Weight of fruit peel }}{\text { Weight of fruit }} \times 100$

\section{Experimental methods}

\section{Preparation of persimmon pulp}

Fully matured, fresh and healthy fruits free from bruises and cracks were selected for the preparation of persimmon pulp. The selected fruits were thoroughly washed in running water to remove any adhering dirt.

The persimmon pulp was prepared by boiling method.

\section{Boiling}

The persimmon fruits were boiled in water for 3-5 minutes in the ratio of fruit: water $=1: 2$ at $100^{\circ} \mathrm{C}$.

\section{Peeling}

The fruits were then cooled at room temperature and then peel was removed.

\section{Pulping}

Pulp was prepared by adding previously used water in boiled segments of fruit in the ratio of fruit: water $=2: 1$ and was blended in an electrical blender.

Preparation of sugar and cinnamon powder: Sugar and cinnamon were ground in an electric grinder separately to obtain powder.

\section{Development of product}

Slab was prepared using persimmon fruit with different combinations of aonla. Ingredients used for preparation of slabs are given in Table 1.

\section{Preparation of slab}

Product A was prepared by mixing all ingredients persimmon pulp, sugar powder, cinnamon powder and salt thoroughly. The mixture was heated for 3-5 minutes. Then it was poured into tray at thickness of $0.25 \mathrm{~cm}$. It was dried for 6 hours at $60^{\circ} \mathrm{C}$ in hot air oven.

Another layer of mixture was poured over it. Process was repeated until a thickness of one $\mathrm{cm}$ was obtained. It was then dried for 24 hours at $60^{\circ} \mathrm{C}$ turning both the sides till it obtained a leathery texture.

Product $\mathrm{B}$ and $\mathrm{C}$ were prepared using the same procedure as for product A except for 
change in ingredients as listed in Table 1 Product A, B and C were cut into rectangular pieces and were packed in plastic bags and stored at room temperature for further analysis.

\section{Sensory evaluation of formulated product}

Formulated product was evaluated for their sensory characteristics by Score Card and Nine Point Hedonic Scale (Amerine et al., 1965) (Appendix I and II). Score Card was used for the evaluation of color, flavor, texture, taste, appearance and overall acceptability. Nine Point Hedonic Scale (1 to 9) ranging from like extremely to dislike extremely was used for the evaluation of acceptability of the product. The evaluation was done by a panel of 10 members of Department of Foods and Nutrition, College of Home Science, GBPUA\&T, Pantnagar.

\section{Packaging and storage of product}

For the purpose of storage analysis, the best acceptable slab was packed in HDPE bags and was kept in a cool and dry place for a period of 60 days at room temperature. During the storage period the best acceptable product (slab) was evaluated for sensory and chemical characteristics.

\section{Statistical analysis}

Data obtained from the formulated product was calculated for its mean values and standard deviation. Comparative analysis of formulated product was done using Analysis of Variance technique-one way classification.

\section{Results and Discussion}

\section{Physical characteristics of persimmon fruit}

The results of physical characteristics of persimmon fruit are presented in Table 2.

\section{Skin colour}

The skin colour of persimmon fruit was reddish yellow. Senter et al., (1991) and Bose et al., (2003) reported that the colour of persimmon fruit ranges from orange red to yellow which is comparable to the findings.

\section{Average fruit weight, diameter and length}

The average weight for fruit was $95.14 \mathrm{~g}$ which is comparable to the reported value of $115 \mathrm{~g}$ of average weight of persimmon fruit (Senter et al., 1991). The average fruit diameter and average fruit length of persimmon fruit was $44.45 \mathrm{~mm}$ and $49.10 \mathrm{~mm}$ respectively.

Srivastava and das (2005) reported average diameter $51.7 \mathrm{~mm}$ and average fruit length of $66 \mathrm{~mm}$ in persimmon fruit. The value obtained in present study was comparable to reported value.

\section{Pulp and peel content}

The persimmon fruit contained 94.30 per cent pulp and 5.67 per cent peel.

\section{Sensory evaluation of the formulated product}

\section{Rating of persimmon slab by nine point hedonic scale}

The results for preference of persimmon slab by Nine Point Hedonic Scale are summarized in Table 3. Product $\mathrm{C}$ had highest mean score of 8.40 among all the products followed by product B (7.40) and product A (6.90) and the differences were found to be significant.

Product $\mathrm{C}$ was liked very much and product $\mathrm{A}$ was liked slightly whereas product B was liked moderately. The differences among them were found to be significant. 


\section{Sensory quality characteristics of persimmon slab}

Results on Sensory quality characteristics of persimmon slab are presented in Table 4.

\section{Color}

The mean sensory score of color for product $\mathrm{C}$ was highest (8.30) among all the products followed by product B (7.80) and product A (7.0) and among these the differences were found to be significant.

\section{Flavor}

For flavor, product $\mathrm{C}$ had the highest mean score of 8.10 among all the products followed by product B (7.60) and product A (7.05) and significant differences were found among them.

\section{Texture}

The mean sensory score of texture for product $\mathrm{C}$ was highest (8.17) and lowest for product $\mathrm{A}$ (6.10).

There were significant differences among them.

\section{Taste}

The mean scores of taste for product $\mathrm{C}$ was highest (8.15) followed by product $\mathrm{B}$ (7.50) and product A (6.62) and significant differences were found among them.

\section{Appearance}

The results for sensory characteristics of appearance showed that product $\mathrm{C}$ had highest mean score of 8.30 among all the products followed by product B (7.60), product $A$ (6.97) and the differences were found to be significant.

\section{Overall acceptability}

For overall acceptability, product $\mathrm{C}$ had the highest mean score of 8.27 among them all the products and lowest in case of product $\mathrm{A}$ (6.35) and the mean score of 7.45 was found to be in case of product $\mathrm{B}$. The differences among these products were found to be significant.

\section{Changes in quality of products during storage}

\section{Physico-chemical changes in persimmon slab during storage}

Based on sensory quality characteristics the best acceptable slab was (Persimmon: Aonla : 60:40). The best acceptable slab was kept for storage for a period of 60 days. The results of Physico-chemical changes in persimmon slab during storage are presented in Table 5.

\section{Moisture}

In fresh persimmon slab the moisture content was 13.16 per cent as against the moisture content of 13.08 per cent at 30 days of storage.

There was a significant decrease in the moisture content upto 60 days of storage period. The decline in moisture content was also reported by Hemlatha and Amutha (2005) in chocolate coated carrot bar.

\section{Acidity}

The acidity content was recorded 0.66 per cent in fresh persimmon slab which increased to 0.85 per cent at 60 days of storage period.

This increase was significant. Hemlatha and Amutha (2005) also reported that the acidity content was increase in chocolate coated carrot bar with increase in storage period. 


\section{Total soluble solids (TSS)}

The total soluble solid content in fresh product was 54.34 and 54.87 at 30 days of storage. It increases significantly upto 60 days of storage period. The increase in TSS was also reported by Hemlatha and Amutha (2005) in chocolate coated carrot barupto 3 months of storage.

\section{$\mathbf{P h}$}

The $\mathrm{pH}$ was recorded 6.94 in fresh slab as against $\mathrm{pH}$ of 6.93 at 30 days of storage. The $\mathrm{pH}$ decreased non-significantly upto 60 days of storage and was recorded 6.88 at 60 days of storage.

\section{Ascorbic acid}

Ascorbic acid exhibited a declining trend with increased storage period. In fresh persimmon slab ascorbic acid content was $39.08 \mathrm{mg} /$ $100 \mathrm{~g}$ as against $25.24 \mathrm{mg} / 100 \mathrm{~g}$ at 60 days of storage. It decreased significantly upto 60 days of storage period. Hemlatha and Amutha (2005) also reported that the ascorbic acid was decreased significantly in chocolate coated carrot bar with increase in storage period (three months).

\section{Changes in sensory quality characteristics of persimmon slab during storage}

The changes in sensory quality of persimmon slab during storage on Nine Point Hedonic scale are presented in Table 6. However the mean sensory scores decreased significantly from 0 day of storage (8.40) to 60 days of storage period (7.20) but the product was liked moderately upto 60 days of storage period. The mean sensory score of persimmon slab for various attributes viz. color, flavor, texture, taste, appearance and overall acceptability during storage are given in Table 7. The mean sensory scores decreased significantly from 0 day to 60 days of storage period but the product was found to be acceptable upto 60 days of storage period.

Table.1 Ingredients used for preparation of persimmon slab

\begin{tabular}{|c|c|c|c|}
\hline Ingredients & Product A & Product B & Product C \\
\hline Persimmon pulp & $200 \mathrm{~g}$ & $160 \mathrm{~g}$ & $120 \mathrm{~g}$ \\
\hline Aonla pulp & - & $40 \mathrm{~g}$ & $80 \mathrm{~g}$ \\
\hline Sugar & $120 \mathrm{~g}$ & $120 \mathrm{~g}$ & $120 \mathrm{~g}$ \\
\hline Cinnamon powder & $0.8 \mathrm{~g}$ & $0.8 \mathrm{~g}$ & $0.8 \mathrm{~g}$ \\
\hline Salt & $1 \mathrm{~g}$ & $1 \mathrm{~g}$ & $1 \mathrm{~g}$ \\
\hline
\end{tabular}

Product A- Persimmon: Aonla :: 100:0; Product B- Persimmon: Aonla :: 80:20; Product C- Persimmon: Aonla :: 60:40

Table.2 Physical characteristics* of persimmon fruit

\begin{tabular}{|l|l|}
\hline Parameter & Persimmon fruit \\
\hline Skin colour & Reddish yellow \\
\hline Average fruit weight $(\mathbf{g})$ & $95.14 \pm 4.12$ \\
\hline Average fruit diameter $(\mathbf{m m})$ & $44.45 \pm 3.37$ \\
\hline Average fruit length $(\mathbf{m m})$ & $49.10 \pm 0.88$ \\
\hline Pulp content $(\boldsymbol{\%})$ & $94.30 \pm 0.23$ \\
\hline Peel content $(\boldsymbol{\%})$ & $5.67 \pm 0.23$ \\
\hline \multicolumn{2}{|c|}{ *Values are mean of five observations } \\
\hline
\end{tabular}


Table.3 Rating of persimmon slab by Nine Point Hedonic Scale

\begin{tabular}{|l|l|l|l|}
\hline Products & Mean Scores & Preference & CD at 5\% \\
\hline Product A & 6.90 & Like slightly & \\
\hline Product B & 7.40 & Like moderately & 0.490 \\
\hline Product C & 8.40 & Like very much & \\
\hline
\end{tabular}

Product A- Persimmon: Aonla :: 100:0

Product B- Persimmon: Aonla :: 80:20

Product C- Persimmon: Aonla :: 60:40

Table.4 Mean scores of sensory quality characteristics of persimmon slab

\begin{tabular}{|l|c|c|c|c|}
\hline Parameters & \multicolumn{3}{|c|}{ Products } & CD at 5\% \\
\hline Color & A & B & C & \\
\hline Flavor & 7.00 & 7.80 & 8.30 & 0.590 \\
\hline Texture & 7.05 & 7.60 & 8.10 & 0.790 \\
\hline Taste & 6.10 & 7.05 & 8.17 & 0.957 \\
\hline Appearance & 6.62 & 7.50 & 8.15 & 0.986 \\
\hline Overall acceptability & 6.97 & 7.60 & 8.30 & 0.773 \\
\hline
\end{tabular}

Product A- Persimmon: Aonla :: 100:0

Product B- Persimmon: Aonla :: 80:20

Product C- Persimmon: Aonla :: 60:40

Table.5 Physico-chemical changes in persimmon slab* during storage

\begin{tabular}{|c|c|c|c|c|c|c|}
\hline \multirow[t]{2}{*}{ Parameters } & \multicolumn{5}{|c|}{ Storage period (days) } & \multirow[t]{2}{*}{ CD at $5 \%$} \\
\hline & $\mathbf{0}$ & 15 & 30 & 45 & 60 & \\
\hline Moisture (\%) & 13.16 & 13.12 & 13.08 & 12.72 & 12.16 & 0.340 \\
\hline Acidity (\%) & 0.66 & 0.74 & 0.77 & 0.82 & 0.85 & 0.139 \\
\hline TSS ( ${ }^{\circ}$ Brix) & 54.34 & 54.45 & 54.87 & 55.28 & 55.74 & 0.131 \\
\hline pH & 6.94 & 6.94 & 6.93 & 6.90 & 6.88 & 0.151 \\
\hline $\begin{array}{l}\text { Ascorbic acid } \\
\text { (mg/100g) }\end{array}$ & 39.08 & 37.20 & 34.64 & 30.84 & 25.24 & 0.309 \\
\hline
\end{tabular}

*Slab = Persimmon: Aonla (60:40)

Table.6 Rating of persimmon slab* by Nine Point Hedonic scale

\begin{tabular}{|l|l|l|l|l|l|l|l|}
\hline Product & \multicolumn{5}{|c|}{ Storage period (days) } & Preference & $\begin{array}{l}\text { CD at } \\
\mathbf{5 \%}\end{array}$ \\
\hline Slab & $\mathbf{0}$ & $\mathbf{1 5}$ & $\mathbf{3 0}$ & $\mathbf{4 5}$ & $\mathbf{6 0}$ & & \\
\hline & 8.40 & 7.92 & 7.50 & 7.41 & 7.20 & $\begin{array}{c}\text { Like very much } \\
\text { to } \\
\text { like moderately }\end{array}$ & 0.450 \\
\hline
\end{tabular}

*Slab $=$ Persimmon: Aonla (60:40) 
Table.7 Mean scores of sensory quality characteristics of persimmon slab during storage

\begin{tabular}{|l|c|c|c|c|c|c|}
\hline Parameters & \multicolumn{5}{|c|}{ Storage period (days) } & CD at 5\% \\
\hline & 0 & 15 & 30 & 45 & 60 & \\
\hline Color & 8.35 & 8.10 & 7.95 & 7.70 & 7.55 & 0.443 \\
\hline Flavor & 8.10 & 8.02 & 7.75 & 7.68 & 7.45 & 0.582 \\
\hline Texture & 8.17 & 7.80 & 7.50 & 7.40 & 7.27 & 0.676 \\
\hline Taste & 8.15 & 7.97 & 7.62 & 7.48 & 7.32 & 0.742 \\
\hline Appearance & 8.30 & 8.10 & 7.67 & 7.50 & 7.42 & 0.636 \\
\hline Overall & 8.27 & 8.10 & 8.02 & 7.70 & 7.50 & 0.568 \\
\hline acceptability & & & & & & \\
\hline
\end{tabular}

*Slab = Persimmon: Aonla (60:40)

It may be inferred from the present study that in order to remove astringency persimmon fruit can be mixed with aonla to prepare slab and enhance the nutritional quality.

\section{References}

Amerine, M.A., R.M. Pangborn and Roseller, E.B. 1965. Principles of sensory evaluation of foods. Academic Press, New York, p 265.

Bose, T.K., S.K. Mitra and Sanyal. 2003. Fruits: Tropical and subtropical $3^{\text {rd }}$ ed. Nayaudyog, Calcutta. pp. 65-124.

Butt, M.S. and Sultan, M.T. 2009. Green tea: nature's defense against malignancies. Crit Rev Food Sci Nutr. 49(5): 463 473.

Dauchet, L., P. Amouyel, S. Hercberg and Dallongeville, J. 2006. Fruit and vegetable consumption and risk of coronary heart disease: a meta-analysis of cohort studies. J. Nutr. 136(10): 2588-2593.

FAOSTAT (2012). Retrieved on May 04, 2019 from: http://faostat.fao.org.

Ferrini, F. and Pennati, L. 2008. Gardens and panoramic views in Tuscany: The ornamental role of persimmons. Adv Hortic Sci. 22(4): 255-260.

George, A.P. and Redpath, S. 2008. Health and medicinal benefits of persimmon fruit: A review. Adv Hortic Sci. 22(4):
244-249.

Hemlatha, G. and Amutha, S. 2005. Standardization and evaluation of chocolate coated carrot candied and osmo dried carrot. Indian J Nutr Diet. 42: 213-222.

Karaman, S., O.S. Toker, F. Yuksel, M.C. Am, A. Kayacier and Dogan, M. 2014. Physicochemical, bioactive, and sensory properties of persimmon-based ice cream: technique for order preference by similarity to ideal solution to determine optimum concentration. $\mathbf{J}$ Dairy Sci. 97(1): 97-110.

Luo, Z. and Wang, R. 2008. Persimmon in China: Domestification and traditional utilization of genetic resources. Adv Hortic Sci. 22(4): 239-243.

Miller, K.L., R.S. Liebowitz and Newby, L.K. 2004. Complementary and alternative medicine in cardiovascular disease: a review of biologically based approaches. Am Heart J. 147(3): 401411.

Parab, S., R. Kulkarni and Thatte, U. 2003. Heavy metals in herbal medicines. Indian J. Gastroenterol. 22(3):111-112.

Plaza, L., C. Colina , B. Ancos, C. SánchezMoreno and Pilar Cano, M. 2011. Influence of ripening and astringency on carotenoid content of high-pressure treated persimmon fruit (Diospyros kaki L.). Food Chem. 130: 591-597. 
Rahman, M.A., A.K.M.S. Islam, A. Khair and Bala, B.K. 2002. Effect of non-polar gases on the storage of persimmon fruits at different temperatures. Pak J Biol Sci. 5: 84-87.

Raskin, I., D.M. Ribnicky, S. Komarnytsky, N. Ilic, A. Poulev, N. Borisjuk, A. Brinker, D.A. Moreno, C. Ripoll, N. Yakoby, J.M. O'Neal, T. Cornwell, I. Pastor and Fridlender, B. 2002. Plants and human health in the twenty-first century. Trends biotechnol. 20(12): 522-531.

Senter, S.D., G.W. Chapman, W.R. Forbus and Payne, J.A. 1991. Sugar and nonvolatile acid composition of persimmon during maturation. J Food Sci. 56(4): 989-991.

Singh, B., J.N. Srivastva, V.S. Verma and Razdan, V.K. 2011. Cultivation of persimmon in India. Rastriya Krishi 6(2): 1-2.

Srivastava, K.K.and Das, B. 2005. Flowering and fruiting behavior of persimmon in
Kashmir valley. Agriculture Science Digest. 25(4): 287-289.

Suzuki, K., S. Tsubaki, M. Fujita, N. Koyama, M. Takahashi and Takazawa, K. 2010. Effects of safflower seed extract on arterial stiffness. Vasc Health Risk Manag. 6(1):10071014.

Tous, J. and Ferguson, L. 1996. Mediterrancan fruit. In: Progress in new crops Arlington. Janick J (ed). ASHS Press, Virginia, USA pp. 416.

Yonemori, K., A. Ikegami, S. Kanzaki and Sugiura, A. 2003. Unique features of tannin cells in fruit of pollination constant non-astringent persimmons. Acta Hortic. 601(1):31-35.

Zhao, D., C. Zhou, Y. Sheng, G. Liang and Tao, J. 2011. Molecular cloning and expression of phytoene synthase, lycopene betacyclase, and beta-carotene hydroxylase genes in persimmon (Diospyros kaki L.) fruits. Plant Mole. Biol. Repo. 29(2): 345-351.

\section{How to cite this article:}

Medha Pandey, Kanchan Goswami, Himani Joshi and Pratima Awasthi. 2020. Evaluation of Sensory Characteristics and Storage Stability of Formulated Product from Persimmon (Diospyros kaki) Fruit. Int.J.Curr.Microbiol.App.Sci. 9(07): 311-319. doi: https://doi.org/10.20546/ijcmas.2020.907.033 